\title{
The Effect of Business Environment and Entre- preneurs' Gender on Perception of Financial Risk in The Smes Sector
}

\author{
- Kozubiková Ludmila, Homolka Lubor, Kristalas Dimitris
}

\begin{abstract}
Small and medium-sized enterprises (SMEs) are crucial, and not only for the Czech economy. Their sustainable growth is important for the economy of most European countries. Because of this, the issues surrounding their financing, government support and public perception are widely discussed. The problems connected with external financing of SMEs are closely related to effective management of financial risk, which can minimize competition, create better financial structure and increase the firm's competitiveness. Our results of the questionnaire survey in the Czech Republic in 2015 were obtained using Structural Equation Modelling (SEM) and revealed a factor which the male sample believed to be an important influence on the perception of financial risk is a bank's approach to business. This factor is significantly influenced by knowledge, rules and principles including the knowledge of banks' credit conditions, their transparency and the ability of entrepreneurs to manage financial risks. In the female sample, state and public perception showed to be much more important in the perception of financial risk. Male entrepreneurs mitigate financial risks through a bank's assistance whereas female entrepreneurs emphasize the role of society.
\end{abstract}

Keywords: small and medium-sized enterprises, financial risk, government support, social environment, banks' approach, Czech Republic

JEL Classification: L26, L53

\section{INTRODUCTION}

Filser, Eggers, Kraus and Málovics (2014) state that the increasing pressure from globalization on today's firms makes it hard to develop enduring competitive advantages, and improve business performance or create sustainable competitive advantage, which are cornerstones of any firm's viability. The results of their study comparing SMEs in Austria and Hungary show that availability of financial resources promote entrepreneurial orientation and SME growth as a result. Furthermore, financial resource availability in general has a significantly positive effect on firm growth. Their study shows that the more financial resources an SME possesses, the more likely it is to be "entrepreneurially oriented," and the more it grows as a result. Therefore, any firm that intends to grow will require entrepreneurial orientation.

Small and medium-sized enterprises (SMEs) are the backbone of the Czech economy, as evidenced by the statistics. For the successful development of small and medium-sized enterprises it is important to create a suitable strategic and institutional framework to support the successful development of appropriate business conditions (Sobotovičová \& Blechová, 2016). According to 
the Czech Statistical Office, data showed business activity of 1124380 SMEs run by legal and natural persons (employing 0-249 persons) on the 31st December 2014. The SMEs proportion of the total number of active enterprises in 2014 was $99,84 \%$. Its proportion of employees in the business sector in the Czech Republic in 2014 amounted to 59,39 \%. The added value of SMEs to the whole of the Czech Republic accounted for 53,11 \%. (Ministry of Industry and Trade, 2015)

SMEs are crucial to competitiveness and productivity; they seem to be better built for survival and may even thrive in a changing and integrated environment. For most of the small firms, the key question is how to finance new entrepreneurial plans. Banks look for a positive company track record and collateral, which generally new firms do not have, particularly those developing knowledge-based activities. Access to finance is the most important constraint in the view of the entrepreneurs. The smaller the firm, the more important the difficulty of financing the new entrepreneurial plans becomes (Samitas \& Kenourgios, 2005).

Because of these facts, it is necessary to pay attention to risk management of SMEs and due to existing obstacles with external financing, it is necessary to concentrate on the financial risk associated with financing: financial transactions that include company loans at risk of default.

\section{THEORETICAL BACKGROUND}

Shuying and Mei (2014) argue that financial risk is one of the major reasons for default of SMEs due to lack of bank financing. Similarly, it is argued that managing financial risk can minimize the competition, by improving better financial structure and increasing production ability. It is also identified that poor capital structure of SMEs is a major reason for their financial risk. SMEs are overwhelmingly dependent on debt financing and as a result their debt ratio is higher in the capital. Therefore, banks charge higher interest rates and due to large debt burden, SMEs default. Hence, the authors propose that effective management of capital structure can reduce debt burden, which in turn may also reduce the financial risk of the SMEs.

Kim and Vonorts (2014) examined risk management practices for young and small firms, those between two-eight years, operating in ten European countries: Croatia, the Czech Republic, Denmark, France, Germany, Greece, Italy, Portugal, Sweden and the UK. They found that when young firm is faced with technological risk, financial risk and operational risk, it engages in networking activities from which they seek help from others. Moreover, the results show that technological and financial risk is highly associated with networking and that small firms can arrange funds to run their operation smoothly when faced with a financial crisis. Nevertheless, two thirds of the respondents replied that market risk is the major risk for the survival of their enterprise (i.e., high competition, low demand for the product, advancement of new designs, narrow market place for selling their products, etc.). Financial risk management and lack of access to funds is also found to be a very significant for risk management in small firms: around $60 \%$ of the respondents think managing aftermarket risk and financial risk is important for their survival.

Korab and Pomenkova (2014) examined the access of SMEs to credit in the Visegrad countries during the period of financial crisis, and they found that SMEs in the Czech Republic and Slovakia show greater reduction in loans and they had very limited access to finance between the 
pre-crisis period of 2006-2007 to 2008-2009. However, the changes in Poland and Hungary are insignificant. It shows that these countries were affected more than Poland and Hungary during the period of financial crisis. It is also possible to say that banks in these countries were even more conservative in providing loans to SMEs after the financial crisis. Hence, SMEs face greater financial constraints in these countries to raising funds for their growth.

An entrepreneur must be a person who is able to accept risk and understand the possibility of failure of his/her decision. In general, women are more risk averse than men. For example, Forlani (2013) indicates that women believe less in their abilities to make financially risky business development-type decisions than men do, and that these beliefs are unsubstantiated. Further, women who receive negatively valued information about the outcomes of their prior decisions' outcomes have lower risk-taking self-efficacies than either men or women received positively valued outcome information. The analysis of Kepler and Shane (2007) shows that male entrepreneurs were significantly less likely than female entrepreneurs to prefer low-risk/low-return businesses.

For most small and medium-sized enterprises, bank credit is the most common and often the only external source of funds. The results of a Bsiness Environment and Enterprise perfomance Survey of Muravyev, Talavera and Schafer (2007), which included 34 countries mostly in Central and Eastern Europe, show that women entrepreneurs are more credit- rationed than the male entrepreneurs. Banks are discriminating based on gender: women received nearly $5 \%$ lower credits than males in the examined countries. Similarly, the results show that banks charged 0,5 percentage points more on interest rates and demanded higher collateral from the women entrepreneurs. However, they also found that financial development of the market can reduce the discrimination in bank financing, due to more information transparency and increased competition in the market. Overall, it is found that women face more credit constraints than their male counterparts and that banks' approaches to financing is still too rigid for female entrepreneurs.

The results of Belluchi, Borisov and Zazzaro (2010), who examined the gender-based discrimination in bank financing in the Italian market using credit fie data from 7800 small businesses, show that female entrepreneurs are faced with some strict conditions in the loan contract: higher collateral, lower credit limits and quicker maturity of the loan. They did not find any discrimination in the pricing of the loans and it suggests that similar interest rates are available for both men and women entrepreneurs. It suggests that a bank's approach to financing female-owned firms is more conservative than the male-owned firms because women entrepreneurs have a lack of management ability, experience and a lower academic level is than their male counterparts.

Kwong, Jones-Evans and Thompson (2012) revealed using the GEM monitor data from 20052007 that there are gender differences in bank approaches to financing SMEs. Their results show that women face more credit constraints than men in terms of accessing bank finance for their business start-ups. They also face discrimination on loan rates. It is argued that banks discriminate against women entrepreneurs due to their poor management skills and lack of previous experience.

The empirical results of Irwin and Scott (2010) suggest that men are more financially constrained than women, due to past repayment history and less commitment to their businesses $(18 \%$ of 
men faced difficulties in financing the start-ups of their businesses compared to $12 \%$ of women: however, the result is not statistically significant at the $5 \%$ level).

Carter, Shaw, Lam and Wilson (2007) found some distinct criteria for loan processing, on both the supply and demand side: it makes a difference whether the loan applicant is male or female, and whether the loan officer is a male or female. They have found that applicant education plays an important role when an application is being considered. Female applicants with a lower level of education are mostly rejected. However, at higher levels of education, the gender criteria for loan processing diminish. It is found that, when the loan applicant is male, the loan officer is more likely to know about the business plan, financial history and general characteristics of the applicant.

Also Rad, Yazdanfar and Öhman (2014) studied the loan process from the view of loan officers and tried to reveal the differences between male and female loan officers. Their findings demonstrate that female loan officers focus more on collateral (used as a proxy for risk aversion) in their evaluations of first-time loan applications than male loan officers. However, the findings also suggest that there are no significant differences between the two groups as far as risk aversion when they evaluate additional loan applications.

However, gender differences in bank financing were not confirmed in the results of Lituchy and Reavley (2004), who indicate that gender-based credit rationing does not occur in the Czech Republic as well as in Poland.

Also according to Iakovleva, Solesvik and Trifilova (2013) there are no gender differences in bank financing found in Russia and Ukraine. Authors found that being a woman is not a disadvantage to get bank loans; both men and women are getting the same priority for bank finance. However, banks are more willing to fund a business which is at least one year old. It is suggests that start-up bank financing is rigid in both countries. Nevertheless, interest rates are high in both countries, which is the major bank obstacle for business financing.

The problem of financing SMEs as engines of economic development - due to their share of GDP not only in the Czech Republic, but in the European Union as a whole - is a widely discussed topic. The government of the Czech Republic evaluates the support of SMEs through regular annual reports. The Report on Development of SMEs and its support in 2014 (Ministry of Industry and Trade, 2015) summarizes the distribution of funds to individual projects by the state, through its ministries or grant agencies. The grant program Operational Programme Enterprise and Innovation was by 31. 12. 2014 exclusively intended for SMEs. From the beginning of its implementation, it has used a total of 48 077,2 million CZK. Altogether in 2014, as part of the TIP program of the Ministry of Industry and Trade, it supported 110 projects submitted by SMEs. The total amount of targeted support, pumped directly to SMEs amounted to 0.342 billion CZK. The report further informs about the new Operational Programme Enterprise and Innovation for Competitiveness and its priority access and specific programs. The operational program is aimed at increasing the number of companies able to move beyond - or at least reach - the technological frontiers in their field, with particular emphasis on business development, research, development and innovation capacities and their connection with the environment. Further development of entrepreneurship and innovation is occuring in fields with lower knowl- 
edge intensity, which brings the focus mainly to supporting the implementation of new business plans: to shift to a more energy-efficient economy and to facilitate business development services and access to services through the broadband.

According to reports, it is evident that women continue to rise in business. The Association of Small and Medium Enterprises and Entrepreneurs of the Czech Republic (AMSP) organizes the project Enterprising Woman, within which, together with the relevant ministries (particularly the Ministry of Industry and Trade and the Ministry of Labour and Social Affairs of the Czech Republic) strongly supports new women entrepreneurs. AMSP simultaneously monitors and evaluates statistics focusing on women in business. An analysis of AMSP shows that by the end of 2014, $35 \%$ of all the self-employed women. It also revealed that, between the years 2009 and 2015 , trade licenses grew for men by 13\% and for women 24\%. (Ministry of Industry and Trade, 2015)

State efforts to support directly men and women in business has changed over time in response to the increased interest of women to join the create business, and therefore may not be perceived positively. Lituchy and Reavley (2004), in a comparison of international small business owners in Poland and the Czech Republic, state that entrepreneurs in the Czech Republic expressed that government support was insufficient for women and they had to comply with lots of paper-work. On top of that, plenty of bureaucratic legislation was also in place. However, the paper finds that women entrepreneurs in both countries relied more on the government for support and grants for business success. The paper also finds that Polish entrepreneurs were more likely to be risk takers than their Czech counterparts were.

However, Klonowski (2010) examined the government supported programs for SME development in Poland and revealed that government support was not efficient. It was also found that entrepreneurs were not well informed about the grant projects and hence, lot of entrepreneurs suffered from lack of credit. Results suggest that women are more dependent on credits from the government support programs to stabilize their businesses than men. However, there was no gender-based discrimination found and it shows that both men and women were equally supported when applying for the grants.

The findings of the research of Iakovleva, Solesvik and Trifilova (2013) find that in Russia and Ukraine most of the women entrepreneurs in both countries are not even aware of any kind of financial support from the government to start an enterprise. There are some entrepreneurs who were aware of the government support but they did not apply due to too much legislative regulations of the funds. Therefore, according to them, female entrepreneurs are not dependent upon the government financial support to manage the financial needs of the business.

The long-term priorities of the Government of the Czech Republic are not only to support women in business, but to reduce the administrative burden on businesses, for both men and women alike. The calculation made for the administrative burden on businesses on of 31. 12 . 2013 shows that the administrative burden on businesses was reduced by 21.1 billion CZK (a decrease of $24.39 \%$ ) compared to 2005, based on 2013 prices. In 2005 prices, it represents a reduction of administrative burden on businesses by $36.82 \%$ (Ministry of Industry and Trade, 2015). The aim is to avoid creating administrative burdens, especially in the lawmaking process, which is also dedicated to Ministry of Industry and Trade in the interdepartmental consultation 
procedure. To identify unnecessary administrative burdens on businesses in the legislation the use of Regulatory Impact Assessment (Regulatory Impact Assessment, - hereinafter "RIA"). The RIA framework of analytical methods leads to a systematic assessment of the expected impact of proposed policies and laws that are implemented. This includes the reduction from of compulsory basic capital that a limited liability company must possess. There is also an acceleration of business start-ups due to the possibility of direct entries in the register of notaries public and higher computerization of court proceedings. Implementation of the proposed measures should contribute to increasing the competitiveness of enterprises, simplify and streamline environmental legislation and bringing Czech law into line with EU law. (Ministry of Industry and Trade, 2015b)

\section{RESEARCH OBJECTIVE, METHODOLOGY, DATA}

The aim of this article is to find out the character and the degree of dependency of determined factors, working title knowledge and rules and principles (KP), banks' approaches to business (BA), state and public perception (SP) on the perception of financial risk (FR) between the male (861 respondents, $75 \%$ ) and female sample (280 respondents, $25 \%$ ) from the questionnaire survey conducted in the Czech Republic in 2015. At the same time, we tried to reveal the nature of the relationship between examined factors.

The companies were chosen from the database Albertina and in total of 1650 randomly selected firms were addressed by e-mail or phone to fill in the questionnaire placed at website

https://docs.google.com/forms/d/1U9coaC5JRL0N2QOOO6Xb8j3mnaZXdSM47Kugt4ED GFo/viewform? usp=send_form. Data was collected in the 14 Czech regions. Although all regions in the Czech Republic were covered, 323 companies were asked in the Zlín region. This bias is caused by the location of the university which carried out the research.

The questionnaire consisted of 52 questions. In the first nine questions, the respondent was asked about their education, gender, age, residency, firm size, lenght of operation, area of conducting business, motives for starting a business and finally, the most important characteristics of entrepreneur were analyzed. The rest of the questions were scale questions on a 1-5 scale (1totally agree, 2-agree 3-do not hold a position, 4-disagree, 5-completely disagree) and focused on five elements of entrepreneurial orientation.

The structure of the sample according to the business area was as follows: trade companies $(33 \%)$, manufacturing companies (23\%), construction companies (14\%), transport companies $(6 \%)$ and agricultural firms $(3 \%)$. The largest portion of companies operated in other sectors $(39 \%)$.

From the total number of 1,141 surveyed firms $65 \%$ were micro-enterprises, $27 \%$ were small enterprises and $8 \%$ were medium-sized enterprises.

The total number of 1,141 companies surveyed, $62 \%$ of them were doing business for more than 10 years, $21 \%$ of them between 1 and 5 years, and $17 \%$ of them between 5 and 10 years. It can be stated that the owners of the companies were quite experienced entrepreneurs. 
This research deals with indirectly observable variables (latent constructs). For the purpose of our article we have determined three factors: working title banks approach to business (BA), knowledge, and rules and principles (KP) and state and public perception (SP). Each of the factors includes several questions chosen from the questionnaire (Table 1).

Tab. 1. - Defining researched factors. Source: own

\begin{tabular}{|c|c|}
\hline Factor & Ouestions of the questionnaire \\
\hline \multirow{7}{*}{$\mathrm{SP}$ - state and public perception } & Government helps us during entrepreneurship. (st1) \\
\hline & $\begin{array}{l}\text { Government creates convenient entrepreneurial envi- } \\
\text { ronment for SMEs. (kv2) }\end{array}$ \\
\hline & $\begin{array}{l}\text { The forms of financial support from government can } \\
\text { be considered as well set. (st } 4 \text { ) }\end{array}$ \\
\hline & $\begin{array}{l}\text { I think that government is bullying us during the } \\
\text { entrepreneurship. (st2) }\end{array}$ \\
\hline & $\begin{array}{l}\text { I evaluate entrepreneurial environment as convenient } \\
\text { for setting up a business. (kv1) }\end{array}$ \\
\hline & $\begin{array}{l}\text { Entrepreneurs and public realize a benefit of entrepre- } \\
\text { neurs for society. (sp3) }\end{array}$ \\
\hline & $\begin{array}{l}\text { Conditions for entrepreneurship improved during last } \\
5 \text { years. }(\mathrm{kv} 3)\end{array}$ \\
\hline \multirow{3}{*}{ BA - banks approach to business } & Banks use too strict criteria during lending proces. (tr3) \\
\hline & Banks accept our needs and come meet us. $(\operatorname{tr} 2)$ \\
\hline & $\begin{array}{l}\text { SMEs have difficult access to external financial } \\
\text { sources. (tr4) }\end{array}$ \\
\hline \multirow{3}{*}{$\begin{array}{l}\mathrm{KP}-\text { knowledge and rules and } \\
\text { principles }\end{array}$} & $\begin{array}{l}\text { The conditions under which banks provide loans to } \\
\text { SMEs are familiar to entrepreneurs. (uv2) }\end{array}$ \\
\hline & $\begin{array}{l}\text { The conditions under which banks provide loans to } \\
\text { SMEs are transparent. (uv3) }\end{array}$ \\
\hline & $\begin{array}{l}\text { Entrepreneurs can manage financial risks well in their } \\
\text { firms. (fr2) }\end{array}$ \\
\hline
\end{tabular}

To assure that all factors are identifiable, Exploratory Factor Analysis (EFA) using minimal residuals estimation technique was selected. After the correlation, a matrix was found. Very Simple Structure (VSS) was employed to identify the optimal number of factors. Maximal value of VSS complexity 1 was achieved with 5 factors, while VSS with complexity 2 was virtually equal and in the range of 3-10 factors. Bayesian information criteria suggests extracting 5 factors. These 
findings do not meet expectations, though, so a compromise solution was used and EFA with 5 factors was made. Orthogonal rotation (varimax) technique was selected. During the iterative process, indicators with low communality, high cross-loadings $(>|0.4|)$ and small single-factor loadings $(>|0.2|)$ were removed. Construct reliability was estimated by Cronbach's alpha on 1000 bootstrapped samples.

Based upon the above presented findings, we have stated the following hypotheses:

H1: There is a statistically significant association between a bank's approach to business and perception of financial risk in both the male and the female sample. This association is significantly more intensive in the male sample than in the female sample.

H2: There is a statistically significant association between state and public perception and perception of financial risk in both the male and the female sample. This association is significantly more intensive in the female sample than in the male sample.

H3: There is no statistically significant association between knowledge and rules and principles and perception of financial risk in either the male or the female sample.

H4: There is statistically significant association between bank's approach to business and knowledge and rules and principles in both the male and the female sample.

H5: There is no statistically significant association between state and public perception and the bank's approach to business in either the male or the female sample.

\section{RESULTS AND DISCUSSION}

The aim of this analysis is therefore to show how the model which was identified on the overall sample is robust when is re-computed on two sub-samples. The original model can be graphically represented in Figure 1 and will be introduced in another study.

Subsample analysis is an important step in any analysis as it provides a detailed look on aspects which might potentially represent a threat to generalizability of results. For example, the gender of entrepreneurs surveyed is imbalanced. In our sample of 1,141 respondents 861 were males $(75.46 \%)$. 


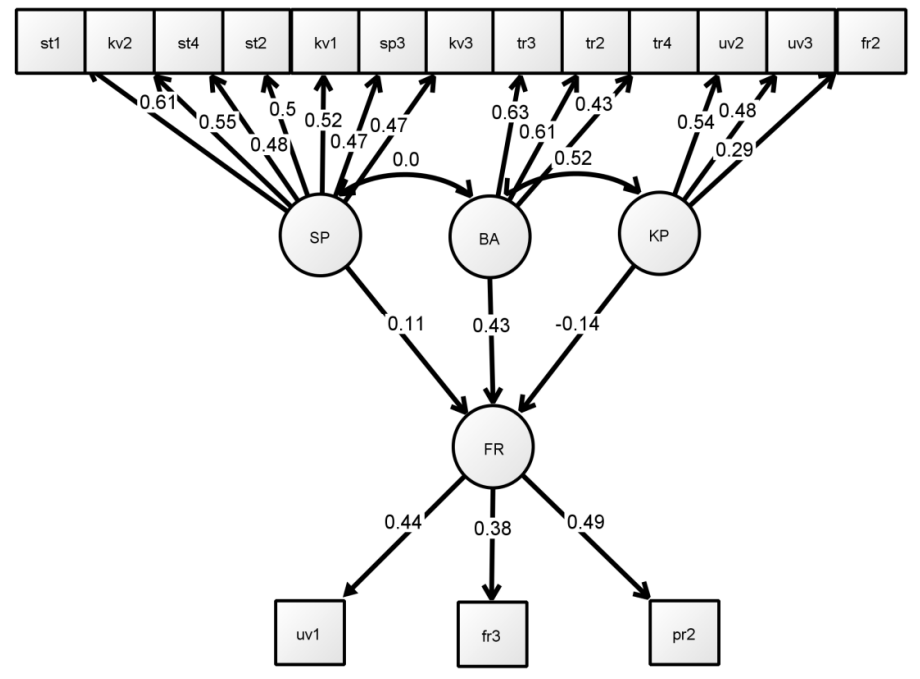

Fig. 1 - Structural model on the complete dataset. Source: own

Constructs were developed using Factor Analysis (FA) with oblique rotation. Corresponding factor loadings were reported in the aforementioned paper. For the purpose of this paper we will not be interested in FA models for separate subsamples, as we are interested in generalizability of the main one. It is, however, useful to analyse whether all items which belong to particular factor are reliable across all subsamples. Table 2 shows bootstrapped estimates of Cronbach alpha (on 1000 replications).

Tab. 2 - Bootstrapped Cronbach alpha estimates. Source: own

\begin{tabular}{|l|c|c|c|}
\hline Construct & Overall & Males & Females \\
\hline SP & 0.77 & 0.77 & 0.75 \\
\hline BA & 0.62 & 0.61 & 0.65 \\
\hline FR & 0.63 & 0.61 & 0.68 \\
\hline KP & 0.52 & 0.52 & 0.51 \\
\hline
\end{tabular}

Received reliability estimates exhibit similar values. These values are below the acceptable value of 0.7 , but, given the large sample size, can still provide some guidance.

There are illustrated associations between SP, BA, KP and FR in the male sample in the Figure 2. Males put more emphasis on the bank's help and perceived financial risks. In general, entrepreneurs feel less financial risks when the bank provides support. This finding is even stronger in the male subsample (effect $=0.52, z=5.008$, p-value $<0.01$ ). H1 was confirmed. 


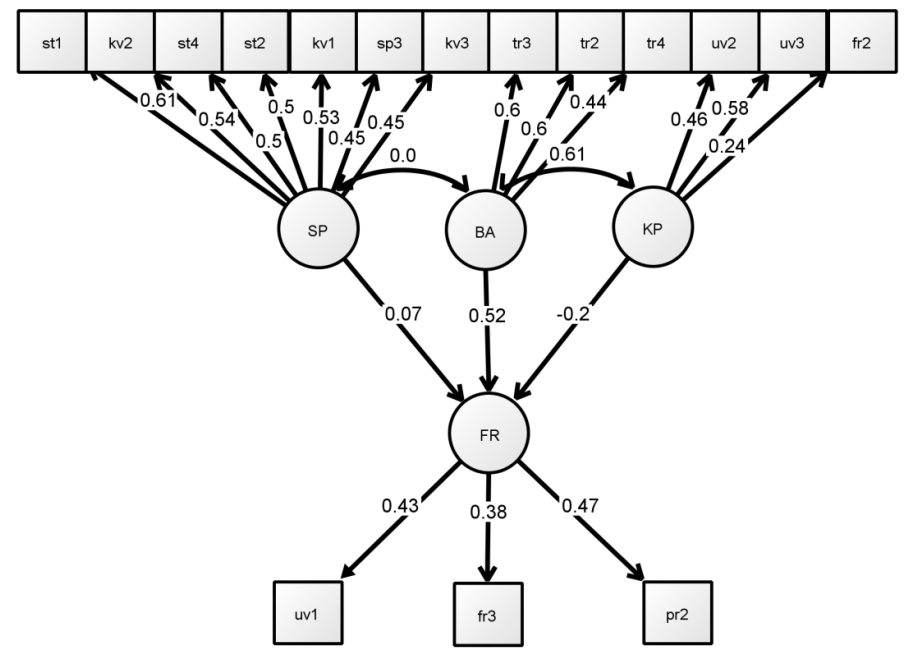

Fig 2 - Structural model - males'sample. Source: own

Results suggest that there is almost no effect of perceived stated and public perception of entrepreneurs activities and financial risks (effect $=0.07, \mathrm{z}=1.400, \mathrm{p}$-val $=0.144$ ). Entrepreneurs who feel weak support from the state and public therefore do not feel the presence of financial risks more than other entrepreneurs.

There is a negative association between KP and perceived financial risks (FR). However, this association is low, though statistically significant ( $z=-2.018,0.044)$. H3 was not confirmed.

In the male sample, a strong correlation (0.61) between perceived BA and KP was stronger than on the female sample. H4 was confirmed.

In the female sample, we find a weaker correlation of BA and KP (effect $=0,24)$. On the other hand, the importance of state and public perception is more important for women entrepreneurs (effect $=0,23$ ). The higher the help from the state and public female-entrepreneurs receive, the better their perception is of financial risks (risks became smaller from pre and post-crisis period). Despite the revealed stronger association between SP and FR in the female sample hypothesis $\mathrm{H} 2$ was not confirmed because the results were not statistically significant.

In both male and female samples, the effect between perceived SP and BA was zero. Even given better state and public perception of business, there is no effect on perceived BA. H5 was confirmed. 


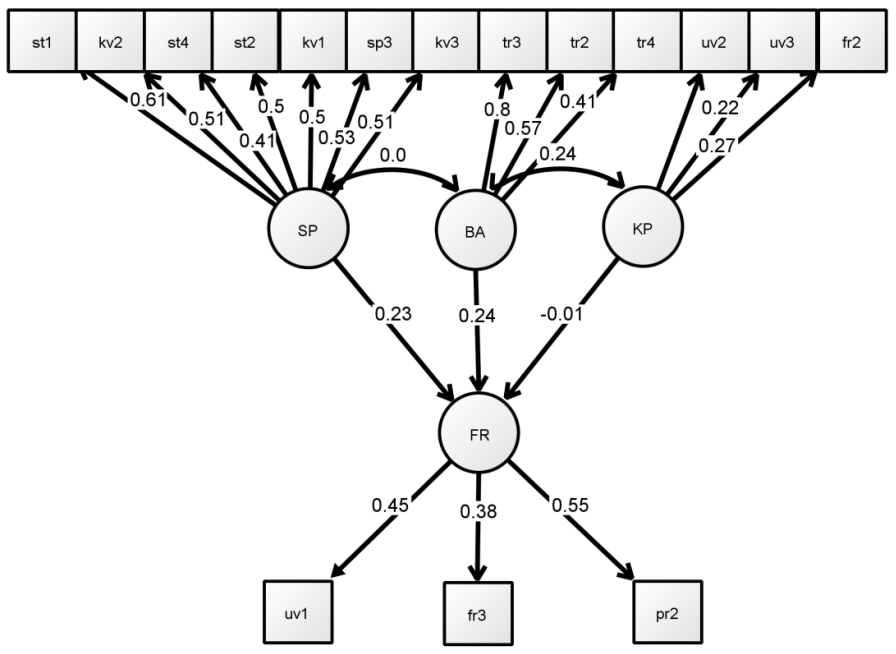

Fig. 3 - Structural model-females' sample. Source: own

All models were probed by standard fit performance indicators. A test based on Chi statistics rejects the null (the observed and theoretical covariance matrices are the same). This finding speaks against the quality of the model as the simplification made by the structural model (removal of some connections between variables). The comparative fit is also not high. This is, however the problem of the overall design (e.g., identification of factors, imprecise questions) which cannot be attributed to subsample analysis. Absolut fit indicators RMSEA and SRMR are almost identical.

Tab. 3 - Absolute fit indicators. Source: own

\begin{tabular}{|c|c|c|c|}
\hline & Overall & Males & Females \\
\hline Comparative Fit Index (CFI) & 0.864 & 0.863 & 0.866 \\
\hline RMSEA & 0.062 & 0.063 & 0.062 \\
\hline SRMR & 0.091 & 0.094 & 0.093 \\
\hline
\end{tabular}

There is a considerable difference between the subsamples. Male entrepreneurs mitigate financial risks through a bank's assistance whereas female entrepreneurs emphasise a role of society. This represents problem to the generalizability of the main model.

It can be stated that our results are compatible with the findings of e. g. Maravyev et. al. (2007), Belluchi et. al. (2010), Kwong et. al. (2012) and Carter et. al. (2007) on existing gender differences in bank loan financing and the consequent perception by women entrepreneurs. These facts are consistent with our findings that women rely more on state and social help in order to mitigate financial risk. The government of the Czech Republic is aware of the increasing number of women in business and try to support them (e.g. Ministry of Industry and Trade, 2015a) but our previous findings showed that entrepreneurs in the Czech Republic do not much 
appreciate state financial support (Ključnikov, Belás, Kozubíková \& Paseková, 2016). We found that only $9.55 \%$ of entrepreneurs rated the applied forms of state financial support as suitably adjusted. There were no statistically significant differences between men and women. In fact, $59 \%$ of entrepreneurs viewed state financial support negatively. On the other hand, we revealed differences in perceptions of public support for entrepreneurship; concretely, women felt more intensive support of their surroundings, than men.

Our results, however, did not confirm the findings of Lituchy and Reavley (2004), Iakovleva et. al. (2013) regarding existing gender differences in perception of bank financing.

According to Ministry of Industry and Trade (2015), women are increasingly aware of the benefits of independence, where a business is not dependent on a single employer. Among the major factors that discourage women from business is the fear that the business might not be supportable. Conversely, the factors that would help them overcome obstacles include increased support for the family, enough money and belief in the demand for the product/service. Fully $79 \%$ of women surveyed perceived at a general level the problem of insufficient state aid; $78 \%$ of women surveyed assess the equally problematic bloated administration associated with the business. These facts support the future strengthening of activities in support of female entrepreneurship and implementation of the envisaged steps in reducing the administrative burden on businesses. Finance and Administration corresponds with the men, but it is clear that women are more cautious and far more sensitive to risk.

It is evident that the government of the Czech Republic through its organizational components, especially the Ministry of Industry and Trade, in conjunction with, for example, AMSP, aims to support small and medium enterprises. According to Ministry of Industry and Trade (2015), the year 2014 was marked by renewed interest in the business community about new loans, especially running. At the historical level of interest rates remained all types of loans, including business. On the other hand, the opinions of entrepreneurs still indicate dissatisfaction with administrative and other barriers to entry into business, including debt financing and unequal access of women and men entrepreneurs.

\section{CONCLUSIONS}

Business risks concern different fields of entrepreneurial activity (market, financial, operational, personnel, technical risk). Financial risk is considered to be one of the most important types of risk because high financial risk-taking may in turn significantly affect the liquidity of the company. It is understandable that its management is receiving considerable attention both in theory and business practice.

Our results show that there are differences between men and women entrepreneurs in factors which are important for the perception of financial risk. While men consider BA to be important for perception of financial risk, women rely much more on state support and public perception of their business.

We have not found any relationship between SP and BA, as we assumed we would. It means the fact that even though the government provides financial and nonfinancial support for SMEs, 
it is independent of the fact that, for example, banks have very strict criteria for loans. KP had also an influence on the perception of financial risk, but it was very weak both in the male and female samples. Furthermore, we found a significant association between BA and KP. This has practical implications. There is a possibility for empowerment of possibilities of different ways of education for entrepreneurs in these areas. Here, we can see a space for more active involvement of economic faculties in the Czech Republic in cooperation with the Ministry of Education a the Ministry of Industry and Trade to implement training courses for entrepreneurs. It is necessary to familiarize entrepreneurs with knowledge concerning bank credit conditions and knowledge in relation to risk management including management of liquidity. According to Farhangmehr, Goncalves and Sarmento (2016) the utility of entrepreneurship education is a frequently discussed question. Entrepreneurial education should stimulate the development of the knowledge base (e.g. knowledge in business management) and entrepreneurial competencies (e.g. behavior traits and skills). However, besides empowering of the students, it is necessary to motivate them to entrepreneurial actions. The results of their study suggest that the prior knowledge emanating from traditional fields in business management, such as marketing, strategy, finance, human resources, business law, accounting, and business ethics, is not decisive in motivating university students to undertake entrepreneurship. Conversely, the results reveal that entrepreneurial competencies significantly influence students' motivation to become the entrepreneurs. The major competencies in such areas as relationships, concepts, organizing abilities and skills, strategy, and commitment are fundamental to motivate the students to do business. In addition to having the knowledge of management, graduate students need to feel confident in their entrepreneurial skills and competencies in order to become motivated to undertake entrepreneurial risks.

Despite the fact that our research has some limitations (e. g. An unbalanced proportion of men and women, regional character etc.), its results have important practical application for policy in relation to SMEs entrepreneurship. It is not enough to declare the intended changes and steps on paper only, but it is necessary to realize them, get feedback and most of all to verify their usefulness.

\section{Acknowledgements}

This paper was created at Tomas Bata University in Zlín and was supported by the Project IGA/FaME/2015/022: The influence of socio-demographic factors on the entrepreneurial orientation of SMEs' entrepreneurs.

\section{References}

1. Angilella, S., Mazzù, S. (2015). The financing of innovativeSMEs: A multicriteriacredit rating model. European Journal of Operational Research, 244 (2), 540-554. http://dx.doi. org $/ 10.1016 /$ j.ejor.2015.01.033

2. Belluchi, A., Borisov, A., Zazzaro, A. (2010). Does gender matter in bank-firm relationships? Evidence from small business lending. Journal of Banking and Finance. 34 (12), 2968-2984. DOI: 10.1016/j.bankfin.2010.07.008

3. Carter, S., Shaw, E., Lam, W. and Wilson, F. (2007). Gender, Entrepreneurship, and Bank Lending: The Criteria and Processes Used by Bank Loan Officers in Assessing Applications. Entrepreneurship Theory and Practice, 31 (3), 427-444. DOI: 10.1111/j.15406520.2007.00181.x

4. Farhangmehr, M., Goncalves, P., Sarmento, M. (2016). Predicting entrepreneurial motivation among university students: The role of entrepreneurship education. Education 
and Training, 58(7-8). DOI: 10.1108/ET-01-2016-0019.

5. Filser, M., Eggers, F., Kraus, S., Málovics, E. (2014). The effect of financial resource availability on entrepreneurial orientation, customer orientation and firm performance in an international context: an empirical analysis from Austria and Hungary. Journal for East European Management Studies, 19 (1), 7-30. DOI: 10.1688/JEEMS-2014-01-Filser

6. Forlani, D. (2013). How Task Structure and Outcome Comparisons Influence Women's and Men's Risk-Taking Self Efficacies: A Multi-Study Exploration. Psychology and Marketing, 30 (12), 1088-1107. DOI: 10.1002/mar.20669

7. Iakovleva, T., Solesvik, M. and Trifilova, A. (2013). Financial availability and government support for women entrepreneurs in transitional economies. Journal of Small Business and Enterprise Development, 20 (2), 314-340.

8. Irwin, D., Scott, J. M. (2010). Barriers faced by SMEs in raising bank finance. International Journal of Entrepreneurial Behavior and Research, 16 (9), 245-259.

9. Kepler, E., Shane, S. (2007). Are Male and Female Entrepreneurs Really That Different? Small Business Research Summary, No 309, 61 pages.

10. Ključnikov, A., Belás, J., Kozubíková, L., Paseková, P. (2016). The Entrepreneurial Perception of SME Business Environment Quality in the Czech Republic. Journal of Competitiveness, 8 (1), 66-78. http://dx.doi.org/10.7441/joc.2016.01.05

11. Klonowski, D. (2010). The effectivenessofgovernment-sponsoredprogrammes in supportingthe SME sector in Poland. Post-Communist Economics, 22 (2), 229-245. DOI: 10.1080/14631371003740738

12. Kim, Y., Vonorts, N. S. (2014). Managing risk in the formative years: evidence from young enterprises in Europe. Technovation, 34, 454-465. DOI: 10.1016/j.technovation.2014.05.0041 0.1016/j.technovation.2014.05.00410.1016/j.technovation.2014.05.004

13. Korab, P., Pomenkova, J. (2014). Financial crisis and financing constraints ofSMEs in Visegradcountries. WIFO working papers, No 485, 16 pages.

14. Kwong, C., Jones-Evans, D., Thompson, P. (2012). Differences in perception pf access to finance between potential male and female entrepreneurs evidence from the UK. International Journal of Entrepreneurial Behaviour and Research, 18 (1), 75-97.

15. Lituchy, T. R., Reavley, M. A. (2004). Women entrepreneurs: A comparison of international small business owners in Poland and the Czech Republic. Journal of International Entrepreneurship, 2, 61-87. DOI: 10.1023/B:JIEN.0000026906.28190.df

16. Ministerstvo průmyslu a obchodu ČR (2015a). Zpráva o vývoji malého a středního podnikání a jeho podpoře v roce 2014. Available on http://www.mpo.cz/dokument164106. html [24.9.2015]

17. Ministerstvo průmyslu a obchodu ČR (2015b). Zpráva o pokroku ve snižování administrativní zátěže podnikatelů za rok 2014. Available on http://www.mpo.cz/ dokument160157.html [9.7.2015]

18. Muravyev, A., Talavera, O., Schäfer, D. (2007). Entrepreneurs Gender and Financial Constraints: Evidence from International data. Discussion Papers 706, German Institute for Economic Research, pp. 1-35 
19. Rad, A., Yazdanfar, D., Öhman, P. (2014). Female and male risk aversion. International Journal of Gender and Entrepreneurship, 6 (2), 121-141.

20. Samitas, A. G., Kenourgios, D. F. (2005). Entrepreneurship, small and medium size business markets and European economic integration. Journal of Policy Modeling, 27 (3), 363374. DOI:10.1016/j.jpolmod.2005.01.004

21. Sobotovičová, Š., Blechová, B. (2016). Perception of business environment by small and medium enterprises [Vnímání podnikatelského prostředí prizmatem malých a středních podniků]. Acta academica karviniensia, 2/2016, pp. 54-66.

\section{Contact information}

Ing. Ludmila Kozubiková, Ph.D.

Tomas Bata University in Zlin, Faculty of Management and Economics

Mostni 5139, 76001 Zlin, Czech Republic

Email:kozubikova@fame.utb.cz.

Ing. Lubor Homolka, Ph.D.

Tomas Bata University in Zlin, Faculty of Management and Economics Mostni 5139, 76001 Zlin, Czech Republic

Email:homolka@fame.utb.cz.

\section{Dimitris Kristalas}

Tomas Bata University in Zlin, Faculty of Management and Economics Mostni 5139, 76001 Zlin, Czech Republic

Email:dimitris.kristalas@gmail.com 